\title{
Benthic Macroinvertebrate Assemblage in Bulod River, Lanao del Norte, Philippines
}

\author{
Charity May L. Dacayana, Jonas T. Hingco, Magdalene Mae L. Del Socorro \\ Natural Science Department, College of Arts and Sciences, Misamis University, \\ Ozamiz City, Philippines \\ Corresponding email: ching_13@yahoo.com
}

\begin{abstract}
Macroinvertebrates are biomonitor species in determining the water quality in freshwater bodies. Benthic macroinvertebrates were assessed in upstream, midstream and downstream of Bulod River, Tubod, Lanao del Norte, Philippines during the month of October-November 2013. The dip net method was used to collect the macroinvertebrates in each station. Identification of species was done using taxonomic keys. A total of 1198 individuals belonging to 24 families of aquatic insects, mollusks, flatworms and aquatic earthworms were identified. Aquatic insects (Class Hexapoda) mostly dominated the area which accounted $91 \%$ of the total abundance. Rarefaction analysis showed highest taxa richness in station 3. Family biotic index (FBI) indicates very good water quality in Station 1 (upstream) and Station 3 (downstream) which is evident by the presence of pollution-sensitive fauna, such as Ephemeroptera, Trichoptera and Plecoptera. The fairly poor water quality in Station 2 (midstream) indicates massive pollution due to various drastic disturbances due to agricultural and other anthropogenic activities.
\end{abstract}

Keywords: aquatic insects, dip net method, freshwater, pollution, species diversity. 


\section{Introduction}

Benthic macroinvertebrates are organisms in the aquatic environment without backbone that live on or inside the deposit at the bottom of a water body. These organisms play an important role in aquatic community, which includes mineralization, mixing of sediments, flux of oxygen into sediments, cycling of organic matter and also in assessing the quality of inland water. Benthic macroinvertebrates species are differentially sensitive to biotic and abiotic factors in their environment. The distribution of these macroinvertebrates fauna is determined by several factors such as the physical nature of the substratum, depth, and nutritive content, degree of stability and oxygen content of the water body (Sharma et al., 2013).

Macroinvertebrates have been used as indicators of environmental conditions especially in evaluating the impacts of specific pollutants in the aquatic environment because of their limited mobility, long life period, their sensitivity to changes in their environment and tolerance of some to contamination (Barbosa et al., 2001; Flores \& Zafaralla, 2012; Sharma et al., 2013; Superales \& Zafaralla, 2008; Tampus et al., 2012). Their community characteristics such as diversity, richness and abundance, are often used as indicators of the degree of pollution of bodies of water, to supplement and deepen the meaning of physicochemical information (Arimoro et al., 2007; Edward \& Ugwumba, 2011; Superales \& Zafaralla, 2008, Flores \& Zafaralla, 2012).

Macroinvertebrates being a biomonitor species in determining eutrophication, pollution and water quality in freshwater bodies are vastly studied in different parts of the world (Edward \& Ugwumba, 2011; Mishra \& Nautiyal, 2013). Currently, there are no existing studies on macroinvertebrate diversity in Bulod River, which is one of the biggest rivers in Lanao del Norte. Apart from this, this river is a tributary of Panguil Bay, which is a rich fishing ground that supports the livelihood of thousands of small-scale fishers in northwestern Mindanao (Jimenez et al., 2009). The water in this river empties into the ocean and may directly or indirectly contribute severe pollution in marine waters affecting the ecological richness and coastal resources particularly in Panguil bay. This study aimed to assess the benthic macroinvertebrates assemblage in Bulod River, Tubod, Lanao del Norte. Specifically this study aimed to determine the species abundance and richness of benthic macroinvertebrates; and to determine the water quality of the sampling sites in terms of Family Biotic 
Index (FBI). The data of this study may serve as the baseline information on benthic macroinvertebrates in the area.

\section{Materials and Methods}

\section{Sampling sites}

Bulod River stretches approximately $21 \mathrm{~km}$ along the northwestern part of Lanao del Norte. Its headwaters start from the mountainous areas of the province and run through some parts of the municipality of Magsaysay and traverse the municipality of Tubod where it empties into the Panguil Bay (Figure 1). To determine the longitudinal profile of Bulod River, three sampling sites were established representing the upstream, midstream and downstream of the river.

Station 1 (upstream) was along the vicinity of Bualan, Tubod, Lanao del Norte $\left(7^{\circ} 59^{\prime} 46.5^{\prime \prime} \mathrm{N}, 123^{\circ} 55^{\prime} 35.3^{\prime \prime} \mathrm{E}\right)$ which was approximately $16 \mathrm{~km}$ from the municipal proper of Tubod with an elevation of about 150 meters above sea-level (masl). This is the area where the headwaters converge. Different activities like bathing and washing are common along the area since the river is the main source of water for the populace. Agricultural activities were also evident as carabaos were found wallowing in the river. Grasses and shrubs were the dominant riparian vegetation with coconut trees surrounding the area and macrophytes scattered along the river banks.

Station 2 (midstream) was located along Barangay Kalilangan ( $8^{\circ} 1^{\prime} 0.4^{\prime}$ 'N, $123^{\circ} 51^{\prime} 3.0^{\prime}$ 'E), which was about $7 \mathrm{~km}$ from the municipal proper, with an elevation of 48 masl. Quary and agricultural activities were observed in the area. Riparian vegetation was only limited to the grass and shrub type. A bridge connecting the towns of Tubod and Magsaysay was constructed across the river.

Station 3 (downstream) was located along Barangay Kakai Renabor ( $8^{\circ} 2^{\prime} 27.4^{\prime}$ 'N, $123^{\circ} 49^{\prime} 29.0^{\prime}$ 'E), which was about $3.6 \mathrm{~km}$ from the municipal proper with an elevation of about 23 masl. Residential activities dominated the area, such as washing and bathing. Riparian vegetation was also dominated by grasses, shrubs and trees, particularly coconut trees, with scattered macrophytes. 


\section{Macroinvertebrate Sampling}

Benthic macroinvertebrates were collected from three sampling stations during the month of October-November 2013. The organisms were collected using D-framed net. The net was positioned facing the upstream. A designated "kicker" disturbed the area upstream at a distance about one meter. The net was lifted out of the water with a forward scooping motion to prevent any of the organisms it contained to wash away; after which the contents of the net were poured into a white basin with water. Non-macroinvertebrates caught were immediately returned to the stream. The collected macroinvertebrates were preserved in $70 \%$ ethyl alcohol on the site and identified in the laboratory up to family level using the reference guide of Bouchard (2004).

\section{Data analysis}

Rarefaction analysis was used to estimate taxa richness in each sampling sites. Family Biotic Index (FBI) was used to measure water quality.

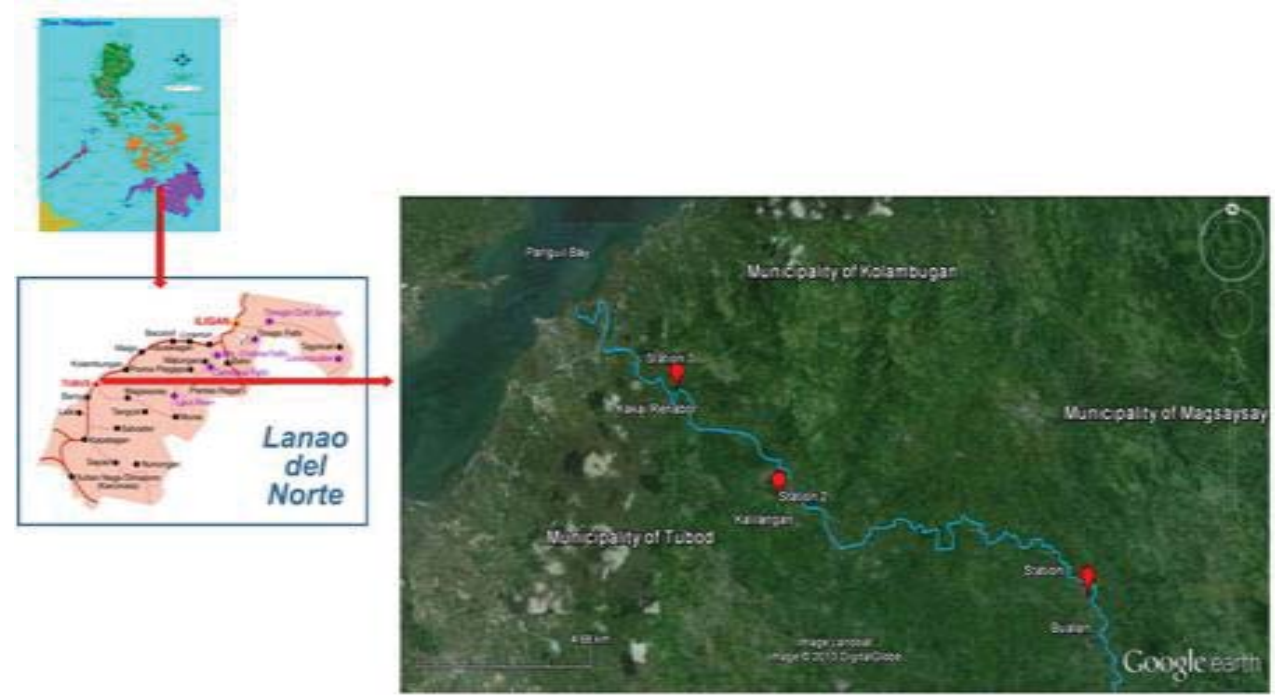

Figure 1. Geographic location of the study area showing the three sampling stations. 


\section{Results and Discussion}

A total of 1198 individuals under 24 families representing six classes were recorded (Table 1). Results on relative abundance (Figure 2) of macroinvertebrates revealed that the dominant organism belongs to Class Hexapoda (91\%). This group of organism is mostly found in very clean waters and is very sensitive to pollution stress. High relative abundance of Class Hexapoda was also reported by Miserendino and Pizzolon (2003), Arimoro et al. (2007), Haileselasie and Teferi (2012), Andem et al. (2012), and Flores and Zafaralla (2012).

Table 1. Macroinvertebrate composition and abundance in Bulod River, Tubod, Lanao del Norte.

\begin{tabular}{|c|c|c|c|c|}
\hline \multirow[b]{2}{*}{ Organisms } & \multicolumn{4}{|c|}{ Number of Individuals } \\
\hline & $\mathrm{S} 1$ & $\mathrm{~S} 2$ & S3 & Total \\
\hline \multicolumn{5}{|l|}{ Class Hexapoda (Insects) } \\
\hline \multicolumn{5}{|c|}{ Order Ephemeroptera (Mayflies) } \\
\hline Family Baetidae & 44 & 1 & 45 & 90 \\
\hline Family Ephemerilidae & 4 & - & - & 4 \\
\hline Family Heptageniidae & 103 & - & 53 & 156 \\
\hline Family Caenidae & - & 2 & - & 2 \\
\hline Family Leptophlebiidae & - & 1 & - & 1 \\
\hline Family Tricorythidae & 5 & - & - & 5 \\
\hline Family Potamanthidae & - & - & 1 & 1 \\
\hline \multicolumn{5}{|c|}{ Order Trichoptera ( Caddisflies) } \\
\hline Family Philopotamidae & 20 & 1 & 62 & 83 \\
\hline Family Hydropsychidae & 64 & - & 37 & 101 \\
\hline Family Hydroptilidae & - & - & 10 & 10 \\
\hline Family Lepidostomatidae & - & - & 3 & 3 \\
\hline \multicolumn{5}{|l|}{ Order Diptera (True flies) } \\
\hline Family Simuliidae & 2 & 1 & 7 & 10 \\
\hline Family Ephydridae & 1 & - & - & 1 \\
\hline \multicolumn{5}{|l|}{ Order Coleoptera ( Beetles) } \\
\hline Family Psephenidae & 104 & 1 & 103 & 208 \\
\hline Family Elmidae & 37 & 2 & 13 & 52 \\
\hline Family Hydrophilidae & 2 & - & 10 & 12 \\
\hline
\end{tabular}


Table 1. Continued: Macroinvertebrates composition and abundance in Bulod River, Tubod, Lanao del Norte.

\begin{tabular}{|c|c|c|c|c|}
\hline \multirow[b]{2}{*}{ Organisms } & \multicolumn{4}{|c|}{ Number of Individuals } \\
\hline & S1 & $\mathrm{S} 2$ & S3 & Total \\
\hline \multicolumn{5}{|l|}{ Order Hemiptera (True Bugs) } \\
\hline Family Gerridae & 28 & 121 & 152 & 301 \\
\hline Family Veliidae & - & 3 & 4 & 7 \\
\hline \multicolumn{5}{|l|}{ Order Plecoptera ( Stone Flies) } \\
\hline Family Perlidae & 12 & - & - & 12 \\
\hline \multicolumn{5}{|c|}{ Order Lepidoptera (Aquatic Moths) } \\
\hline Family Pyralidae & 21 & 3 & 9 & 33 \\
\hline \multicolumn{5}{|l|}{ Class Turbellaria (flatworms) } \\
\hline \multicolumn{5}{|l|}{ Order Seriata (planarians) } \\
\hline Family Planariidae & 1 & - & - & 1 \\
\hline \multicolumn{5}{|l|}{$\begin{array}{l}\text { Class Gastropda (snails) } \\
\text { Order Meseogastropoda }\end{array}$} \\
\hline Family Thiaridae & - & 32 & 44 & 76 \\
\hline \multicolumn{5}{|l|}{ Order Archaegastropoda } \\
\hline Family Neritidae & - & - & 8 & 8 \\
\hline \multicolumn{5}{|c|}{ Class Bivalia ( clams and mussels) } \\
\hline Family Sphaeriidae & - & 7 & 10 & 17 \\
\hline Class Oligochaeta & - & 4 & - & 4 \\
\hline Total no. of taxa (families) & 15 & 13 & 18 & \\
\hline Total no. of individuals & 448 & 179 & 571 & 1198 \\
\hline
\end{tabular}

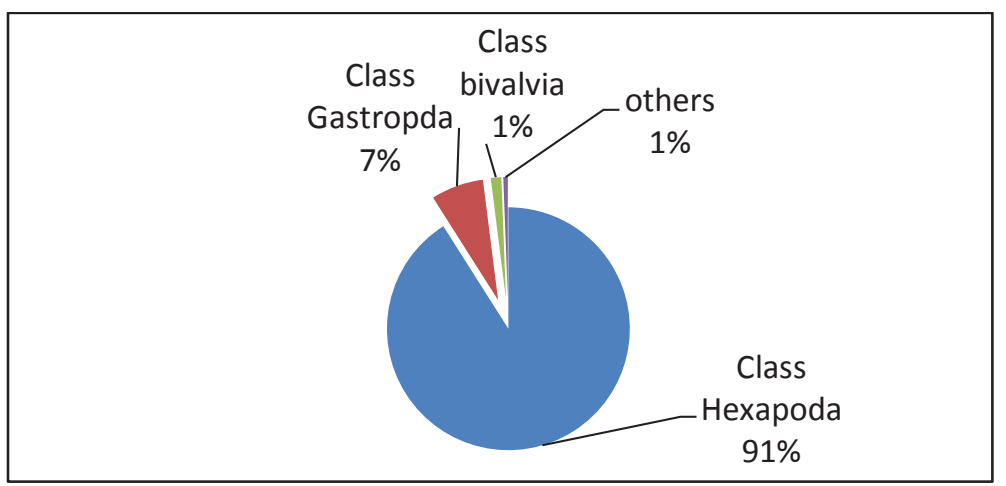

Figure 2. Relative abundance of macroinvertebrates per class in Bulod River, Tubod Lanao del Norte. 
Station 3 in Kakai Renabor, Tubod, Lanao del Norte, had the highest number of individuals. Water striders in Family Gerridae were the most dominant species (152 individuals) which represented $50.6 \%$ of the relative abundance of the total species downstream. This species was the most represented taxon in all stations and most frequently observed on surface waters. Water striders are very conspicuous and may occur in large groups but are rarely eaten by aquatic animals such as fish (Stonedahl \& Lattin, 1982). The vast number of this fauna in the area was associated with thick vegetation around the margins of the river.

The insect orders Ephemeroptera (mayflies), Plecoptera (stoneflies) and Trichoptera (caddisflies) collectively known as EPT are good indicators of water quality because of their sensitivity to pollution. They were found in the three stations but were relatively highest in Station 1 (Bualan, upstream) (54\%) and Station 3 (Kakai, downstream) (45\%) (Figure 3). High species richness of EPT indicates good water quality (Mandaville, 2002).

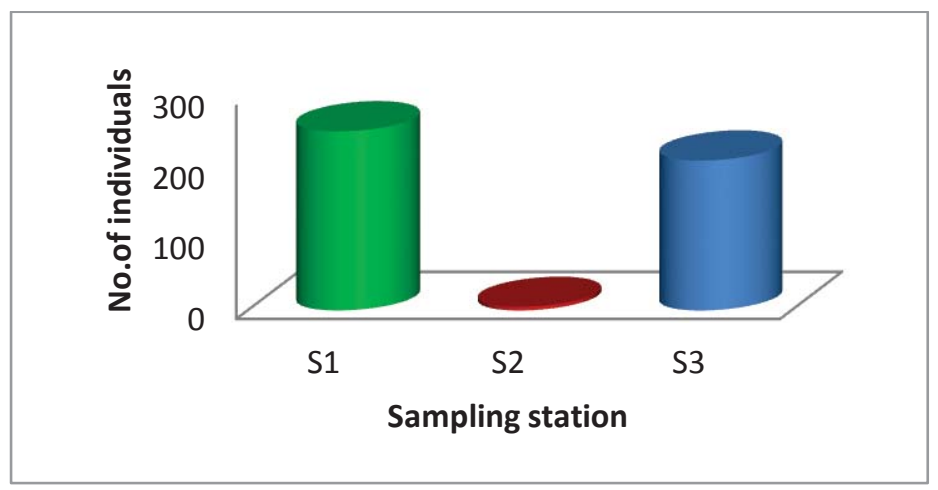

Figure 3. Number of Ephemeroptera, Plecoptera and Tricoptera (EPT) individuals in three sampling stations of Bulod river, Tubod, Lanao del Norte.

In Station 1, the most dominant species (34.8\%) were mayflies (Order Ephemeroptera), and water beetles (Order Coleoptera) (31.9\%). The presence of these insects signifies good water quality since they are sensitive to pollution. Mayflies are most common and abundant in stream riffles and pools because the majority of their life is spent in the water as larvae, their adult individual only lives for one to two days (Bouchard, 2004). Water penny (Family Psephenidae) of Order Coleoptera had the highest number of individuals in the station. This organism cannot live in 
polluted habitats where rocks have a thick layer of algae, fungi or organic sediments (Tampus et al., 2012). The presence of Coleoptera together with other less tolerant species such as Ephemeroptera, Plecoptera, Trichoptera and Odonata in the aquatic system reflects clean water conditions (Miserendino \& Pizzolon, 2003; Emeri \& Nasiru, 2007). The presence of pollution tolerant species such as Tubellaria could be attributed to the effects of domestic waste and other anthropogenic activities evident in the river which is similar to the findings of Sharma et al. (2013). Some species of true flies (Order Diptera) $(0.7 \%)$ and aquatic moths (Order Lipedoptera) $(4.7 \%)$ were also evident in the area.

Station 2 was mostly dominated with waters striders (Order Himeptera) (69.27\%) and snails (Order Meseogastropoda) (17.88\%) which are pollution tolerant organisms (Bouchard, 2004). The presence of snails suggests potential pollution in the area most probably because the area is vulnerable to various impacts such as quarry activity, domestic wastes, and vehicles passing by as the bridge was constructed across the river, agricultural activities such as animals wallowing and wading in the river, and other anthropogenic activities. These activities could have altered the physical and chemical quality of water necessary for the occurrence of macroinvertebrates. The study of Olomukoro and Azubuike (2009) reported that high abundance of mollusk (snails) could be attributed to the level of $\mathrm{pH}$. Slight decrease in acidity and increase in alkalinity, may account for the abundance of mollusk.

In Station 3, water striders (Order Hemiptera) (27.32\%), water beetles (Order Coleoptera) (22.07\%) and caddisflies (Order Trichoptera) (19.61\%) were the most dominant fauna. High abundance of water striders in the area could be attributed to thick vegetation along the margins of the bank. This fauna also is rarely eaten by fishes because of the scent gland secretions which is believed to be responsible for that apparent immunity (Stonedahl \& Lattin, 1982). The presence of water penny, an aquatic beetle (Family Psephenidae) indicates good water quality since they belong to the sensitive species. However, caddisflies (Order Trichoptera) which were also found in the area could tolerate a wide range of environmental conditions.

Rarefaction analysis was used to determine taxa richness in each sampling stations. It is considered useful when comparing communities sampled with very different intensities. This method was used in order to estimate expected taxa richness of the site with highest density if it was sampled at a density similar to that of the site with lowest density 
(Rossi, 2011). Rarefaction results showed that family-level taxa accumulation in three sampling stations was not identical (Figure 4). It revealed that rarefied taxa richness is highest in station $3(S=24)$ and lowest in station $1(\mathrm{~S}=15)$. Rarefied taxa richness for station 3 is 24 , however only 17 taxa were observed in the actual sample. On the other hand, Station 2 had the lowest abundance (179 individuals) and taxa richness $(S=13)$ of benthic macroinvertebrates sampled, yet rarefied taxa richness was 20. It implies that the low abundance and taxa richness in this station might be due to low sample size and individual density. Thus, there is a greater probability of finding rarer families in samples with higher count. Furthermore, species spatial patterning such as aggregation and environmental heterogeneity may lead to more species being sampled at low sampling intensity (total number of individuals counted) (Rossi, 2011). Low taxa richness observed may also indicate devastating impact of impoundment on the benthic macroinvertebrate and pollution stress in the area due to increased human activities (Arimoro et al., 2007; Andem et al., 2012; Edward \& Ugwumba, 2011; Latha \& Thanga, 2010). Romero et al. (2013) added that areas with some fragmentation and siltation points and pasture surrounding riparian vegetation significantly affect community richness, which was also observed in the area.

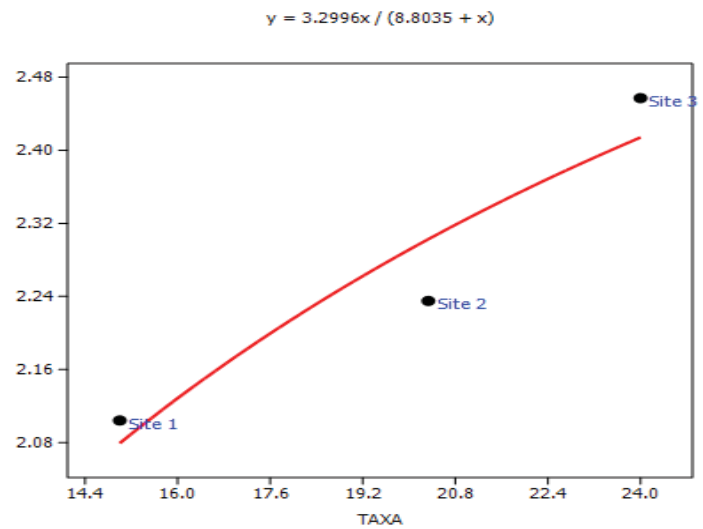

Figure 4. Rarefaction curve of taxa richness of benthic macroinvertebrates in different sampling sites (stations).

Family-level Biotic Index (FBI) (Hilsenhoff, 1988) was measured to detect organic pollution. It is based on family level identification of 
stream arthropods including insects, amphipods and isopods. This index is not as sensitive as species-based indices but it has an advantage for rapid stream assessment. It is a quantitative measure that requires counting of individuals in each family. It is based on the scale of 10 and high values indicate high pollution intolerance while lower values indicate low pollution intolerance (Tampus et al., 2012).

Table 3 shows the water quality of the three sampling stations of Bulod River, Tubod, Lanao del Norte using FBI. Results showed that water quality in Stations 1 and 3 was very good which indicates possible slight organic pollution and Station 2 is fairly poor indicative to have substantial pollution. Station 2 (midstream) was very vulnerable to drastic disturbances such as quarry system, animals wallowing in the water and other human disturbance which may affect the condition of the waters in the area. The study of Tampus et al. (2012) reported that the sites that were mostly impacted were characterized by the presence of silted banks with little or no vegetation in the riverbanks, presence of household wastes and agricultural waste, which were evident in Station 2. Very good water quality in Stations 1 and 3 was manifested with its high richness and abundance of pollution sensitive fauna such as Ephemeroptera, Plecoptera and Trichoptera (EPT). These areas were characterized to have thick riparian vegetation along the river bank which directly influenced the community structure of aquatic insects by inputs of nutrients and allochthonous energy (Romero et al., 2013; Barbosa et al., 2001). The same results were also reported by Miserendeno and Pizzolon (2003).

Table 3. Water quality of the three sampling stations of Bulod River, Tubod, Lanao del Norte using Family-level Biotic Index (FBI) (Hilsenhoff, 1988)

\begin{tabular}{llll} 
Stations & FBI & Water quality & Degree of Organic Pollution \\
\hline S1 (Bualan) & 3.96 & Very Good & Possible slight organic pollution \\
S2 (Kalilangan) & 6.27 & Fairly Poor & Substantial pollution \\
S3 (Kakai) & 3.94 & Very Good & Possible slight organic pollution \\
\hline
\end{tabular}




\section{Conclusion and Recommendations}

The study revealed that Bulod River was dominated mostly by aquatic insects (Class Hexapoda), which was $91 \%$ of the total abundance. Rarefaction analysis showed highest taxa richness in Station 3 and lowest in Station 1. Family biotic index showed very good water quality in Stations 1 and 3, indicative of possible slight organic pollution. The very poor water quality in Station 2, an indicative of substantial organic pollution, was due to various agricultural and other anthropogenic activities.

Further studies are necessary to determine the physicochemical parameters and to assess the seasonal variations of benthic macroinvertebrate diversity to better assess the water quality in the area.

\section{Acknowledgment}

The authors are thankful to Misamis University for providing the research fund. The faculty and staff of Natural Science Department are also acknowledged for their support.

\section{Literature Cited}

Andem, A. B., Okorafor, K. A., Udofia, U., Okete, K. A., \& Ugwumba, A. A. A. (2012). Composition, distribution and diversity of benthic macroinvertebrates of Ona River, Southwest, Nigeria. European Journal of Zoological Research, 1 (2), 47-53.

Arimoro, F. O., Ikomi, R. B., \& Efemuna, E. (2007). Macroinvertebrate community patterns and diversity in relation to water quality status of River Ase, Niger Delta, Nigeria. Journal of Fisheries \& Aquatic Science, 2(5), 337-344.

Barbosa, F. A. R., Callisto, M., \& Galdean, N. (2001). The diversity of benthic macroinvertebrates as an indicator of water quality and ecosystem health: A case study for Brazil. Aquatic Ecosystem Health \& Management, 4(1), 51-59. 
Bouchard, R. W. (2004). Guide to aquatic invertebrates of the upper midwest: identification manual for students, citizen monitors, and aquatic resource professionals. University of Minnesota, St. Paul, MN: Water Resources Research Center.

Edward, J. B., \& Ugwumba, A. A. A. (2011). Macroinvertebrate fauna of a tropical Southern Reservoir, Ekiti State, Nigeria. Continental J. Biological Sciences, Wilolud Journals, 4 (1), 30-40.

Emeri, M. C., \& Nasiru, C. E. (2007). Macroinvertebrates as indicator of water quality of an urbanized stream Kadona, Nigeria. Journal of Fisheries International, 2 (2), 152-157.

Flores, M. J. L., \& Zaffaralla, M. T. (2012). Macroinvertebrate composition, diversity and richness in relation to the water quality status of Mananga River, Cebu, Philippines. Philippine Science Letter, 5(2), 103-113.

Haileselasie, T. H., \& Teferi, M. (2012). Influence of water quality on the diversity and distribution of macroinvertebrates in Hiwane Second Order Stream, Northern Ethiopia. Research Journal of Environmental and Earth Sciences, 4(4), 475-481.

Hilsenhoff, W. L. (1988). Rapid field assessment of organic pollution with a family-level biotic index. Journal of the North American Benthological Society, 65-68.

Jimenez, J. U., De Guzman, A. B., Jimenez, C. R., \& Acuña, R. E. (2009). Panguil bay fisheries over the decades: Status and management challenges. Journal of Environment and Aquatic Resource, 1(1), 1531 .

Latha, C., \& Thanga, V. (2010). Macroinvertebrate diversity of Veli and Kadinamkulam lakes, South Kerala, India. Journal of Environmental Biology, 31, 543-547. 
Mandaville, S. M. (2002). Benthic macroinvertebrates in freshwaters: Taxa tolerance values, metrics, and protocols. Canada: Soil \& Water Conservation Society of Metro Halifax.

Miserendino, M. L., \& Pizzolon, L. A. (2003). Distribution of macroinvertebrate assemblages in the Azul-Quemquemtreu river basin, Patagonia, Argentina. New Zealand Journal of Marine and Freshwater Research, 37(3), 525-539.

Mishra, A. S., \& Nautiyal, P. (2013). Functional composition of benthic macroinvertebrate fauna in the Platues Rivers, Bundelkhand, Central India. Journal of Threatened Taxa, 5(13), 4752-4758.

Olomukoro, J. O., \& Azubuike, C. N. (2009). Heavy metals and macroinvertebrate communities in bottom sediment of Ekpan Creek, Warri, Nigeria. Journal of Biological Sciences, 2(1), 1-8.

Sharma, S., Sudha, D., \& Dave, V. (2013). Macroinvertebrate community diversity in relation to water quality status of Kunda River, (M.P), India. Discovery Publication, 3(9), 40-46.

Stonedahl, G., \& Lattin, J. (1982). The Gerridae or water striders of Oregeon and Washington (Hemiptera: Heteroptera). Agricultural expirement station. Technical Bulletin 144, Oregon State University, Corvallis, Oregon.

Superales, J. B., \& Zafaralla, M. T. (2008). Distribution of benthic macroinvertebrates at Malubog Bay of Moro Gulf, Western Mindanao, Philippines. Journal of Environmental Research and Development, 2(3), 303-313.

Romero, R. D. M., Ceneviva-Bastos, M., Baviera, G. H., \& Casatti, L. (2013). Community structure of aquatic insects (Ephemeroptera, Plecoptera, and Trichoptera) in Cerrado streams of Paraguay, Paraná, and São Francisco river basins. Biota Neotropica, 13(1), 97-107. 
Rossi, J. P. (2011). Rich: An R package to analyse species richness. Diversity, 3(1), 112-120. doi:10.3390/d3010112

Tampus, A. D., Tobias, E. G., Amparado, R. F., Bajo, L., \& Sinco, A. L. (2012). Water quality assessment using macroinvertebrates and physico-chemical parameters in the riverine system of Iligan City, Philippines. Environmental Sciences-International Journal of the Bioflux Society, 4(2), 59-68. 